Number of article: 632

Received: April 9, 2020

Accepted: May 8, 2020
Mechanical Engineering - Scientific Journal, Vol. 38, No. 1, pp. 73-80 (2020)

In print: ISSN $1857-5293$

On line: ISSN 1857-9191

UDC: $621.876: 681.51]: 004.42 .047$

https://doi.org/10.55302/MESJ20381632073j

Original scientific paper

\title{
IMPLEMENTATION OF A SMART ELEVATOR
}

\author{
Kristina Jakimovska, Vojdan Karatrajkov, Anita Vasileva \\ Faculty of Mechanical Engineering, "Ss. Cyril and Methodius" University in Skopje, \\ P.O. Box 464, MK-1001 Skopje, Republic of North Macedonia \\ kristina.jakimovska@mf.edu.mk
}

\begin{abstract}
A b s t r a c t: Elevators are one of the most important mediums of transport in many buildings and working environments. With the development of the architecture, the buildings are getting higher and logically needs to upgrade the way the elevators are currently working or to predict the errors before they happen. The solution lies in changing the current system with a PLC (programmable logic controller). On the other hand, minimization of errors in combination with eco-friendly solutions is the new purpose. This new point of view, which focuses on minimizing and reducing errors, vibrations, more economically is named green elevator. Related to the idea of using green elevators and making buildings more environmentally friendly, the main goal of this paper is to give a new, "green" direction to elevators.
\end{abstract}

Key words: elevator; programmable logic controller; smart technology; eco-friendly

\section{ИМПЛЕМЕНТАЦИЈА НА ПАМЕТЕН ЛИФТ}

\begin{abstract}
А п с т р а к т: Лифтовите се еден од најважните транспортни медиуми во многу објекти и работни средини. Со развојот на архитектурата сѐ почесто се градат повеќекатници и потребно е да се усоврши начинот на кој ифтовите работат моментално, но и да се предвидат грешки кои можат да настанат и тие да се избегнат. Решението лежи во замена на моменталиот систем со програмабилни логички управувачи (РLC). Oд друга страна, новата цел е и минимализација на грешките во комбинација со еколошки решенија. Тоа ново гледиште, кое се фокусира на намалување на грешките, на вибрациите и дизајнирањето на поекономични лифтови, се нарекува 'зелен' лифт. Во врска со идејата за користење зелени лифтови и поеколошки објекти е и главната цел на овој труд - да отвори нова, ‘зелена' насока за лифтовите.
\end{abstract}

Клучни зборови: лифт; програмабилен логички управувач; паметна технологија; еколошки

\section{INTRODUCTION}

Science improves in different ways for a really simple reason - making the life simpler of the human kind in every aspect. Climbing the stairs can be a difficult activity for many people so the first step was to make mechanisms for a vertical transport and that's how the elevator was born. But there is a need for their improvement. Nowadays, with the fast way of living, there is a need for a faster transport from one floor to another with more efficiency and less energy consumption [1]. The life as it is right now cannot be imagined without the elevators. The elevator statistics showed in 2015 that the global demand for elevator equipment and associated services had a total value of $\$ 88.78$ billion and by 2021 the industry is forecast to have a global increase of $\$ 125.22$ billion (source: Statista, 2017). Other data show that in the USA, there are more than 19,000 companies that are currently engaged in the elevator installation. These companies are responsible for the direct employment of about 107,000 people each year (source: Statista, 2017) [13] (Figure 1). 


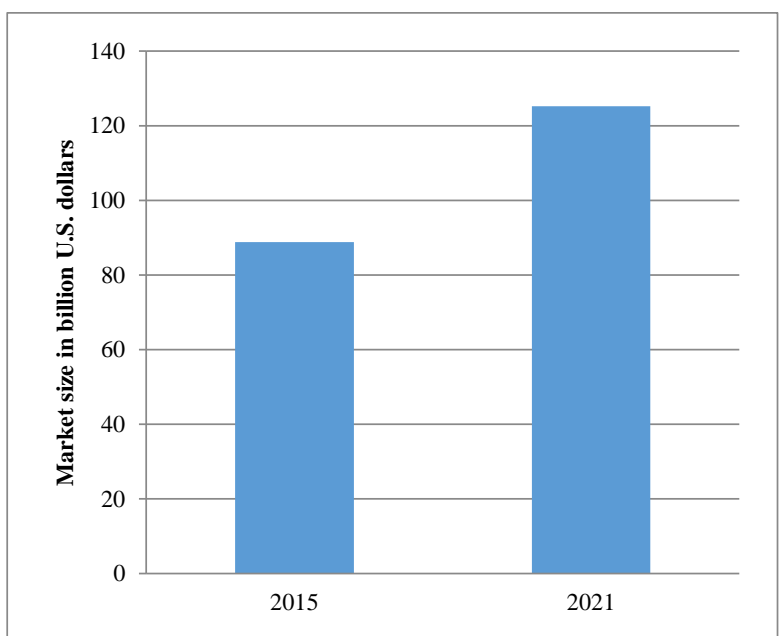

Fig. 1. Global elevator and escalator market size in 2015 and 2021 (in billion U.S. dollars) (Source: Statista, 2017)

Generally, that information shows that elevators are highly involved in our lives. In the aspect of energy efficiency, many case studies and practical testing were comparing hydraulic and cable elevators and it was concluded that the hydraulic models spent 30 times more energy than the cable elevator. The traditional electrical control system of the elevators is based on a relay-controlled system. It's easy to build but it has many disadvantages because of the complicated circuits, high-fault ratio and in many cases poor dependability. [1]

All of these problems affect the elevator's running quality. Because of this matter, the "oldfashioned" relay-controlled elevators evolved into PLC-controlled systems [1,2]. The result showed that the reformed system is highly reliable in operation and as well it is easy for maintenance.

This case study introduces the basic structure, control principle and the method of realization of the elevator with PLC system in detail. Moreover, there is another idea presented in this case study and it is based on a PLC system. It is called the CAN model and will be explained through the paper.

\section{SYSTEM STRUCTURE}

The main purpose of the control system of an elevator is to manage movements of an elevator in response to the user's requests. It is mainly composed of 2 parts:

- electrical power driving system,

- signal control system.

The electric driving system includes the following: elevator car, the traction motor, door motor, brake mechanism, relevant switch circuits.
Throughout developing a new system, the new type of IC (Indicator and Capacitor) series AC contactors was adopted to replace the old ones, and used PLC's contacts to change the numerous relays.

The circuits of the traction motor are reserved. In addition the original control cabinet's disadvantages such as high noise of the driving motor and many vibrations are overcome.

Control signals of the elevators are mainly realized by PLC [3]. The inputs are: operation modes, op-control signals, calls for the cabin, calls from the hall, safety signals, door open/close and many more. All of the above mentioned functions are controlled by PLC and given in the control system diagram shown on Figure 2.

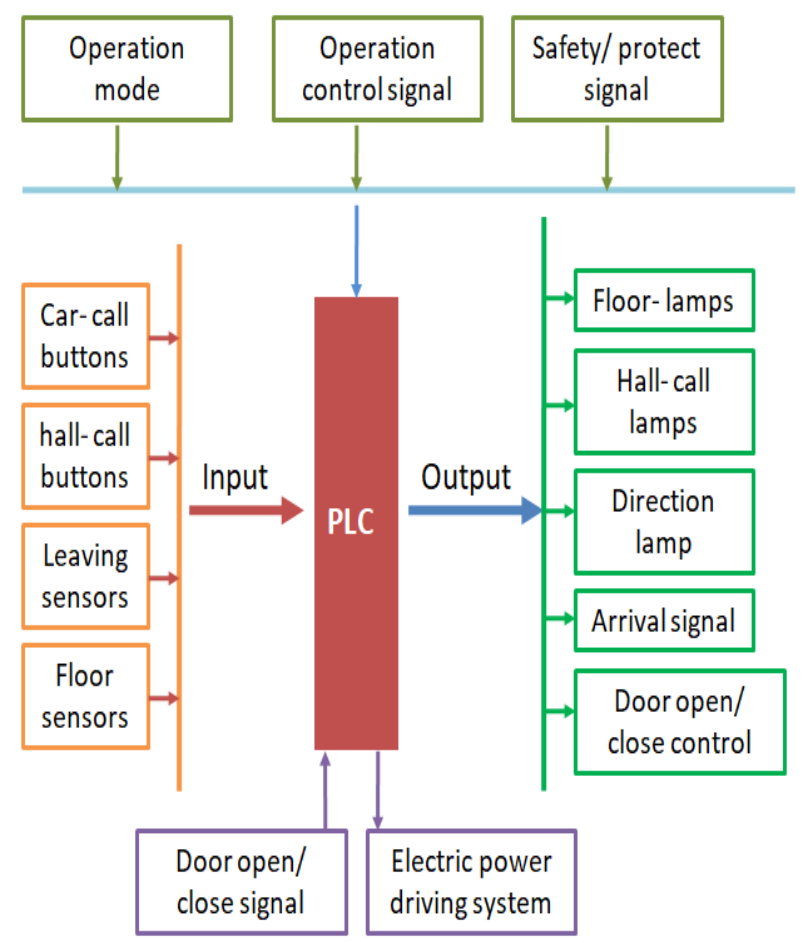

Fig. 2. PLC signal control system diagram

The PLC collects data from the sensors or the input devices, processes them, and after that generates outputs which are based on pre-programmed parameters. Programmable logic controllers are adaptable to almost any application.

Now that it's a little bit clearer about the PLC and their way of functioning we can go back to the case.

There is a big advantage when PLCs are used. They ensure high reliability, as well are designed to achieve small space requirements, the cost is reduced. The PLC scheme is shown in the Figure 3. It 
includes digital/analog input and digital outputs. These can be used as the user requires, as well can be extended using special types of extension cards.

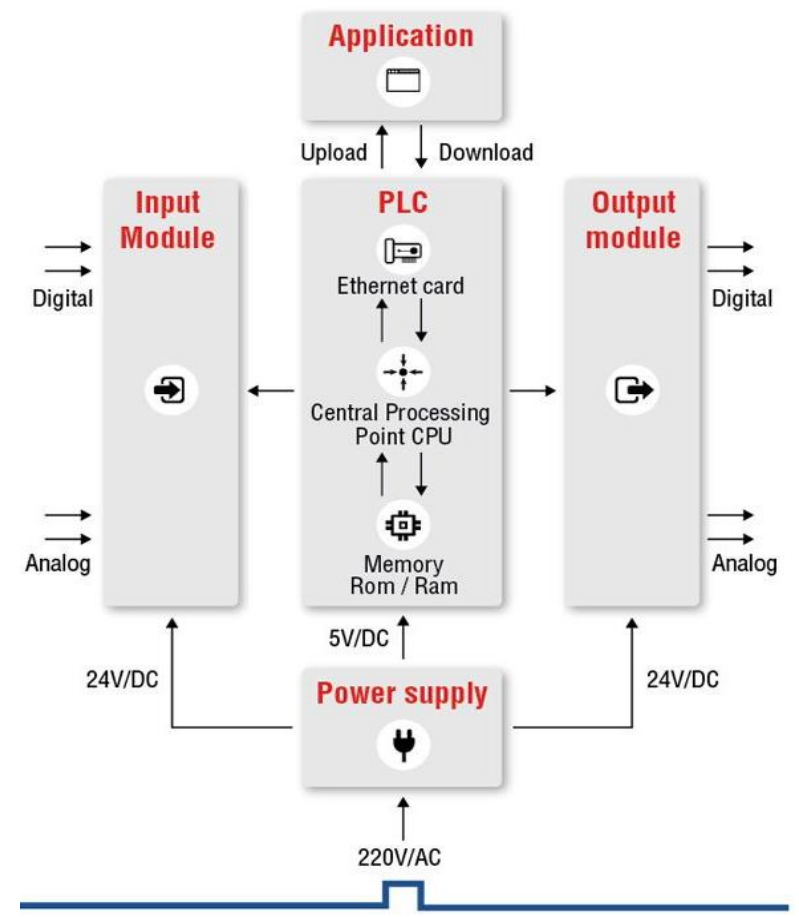

Fig. 3. PLC's digital/analog input and digital outputs

The goal is to develop a control system which will control two elevators in a 9-storey building. Its use is to vertically transport people. For each of the two elevators, there is a sensor located at each floor. The sensor can be used to locate the current position of the elevator at each moment. The elevator's door can be opened/closed by a motor in the door. The second sensor on the door can inform the system of control about the position of the door when it is closing. There are more sensors which indicate when the door should stop closing if an object is blocking the door or many contact boards which everything connects itself with a logic of a mechatronic system. And everything is easily controlled with a PLC and with a newly raised technology called CAN-model [3].

There are numerous possible situations where an elevator could use PLC. In this paper the possibilities will be only mentioned with the most important information. So, when it comes to implementation of PLC in elevators, there are a few possibilities.

One approximate small-scale elevator prototype with PLC is adopted for the controller design which uses "ladder language" which is based on the
GE FANUC VersamaxPLC. The ladder logic has is using VersaPro as a platform [4].

Light Dependent Resistor (LDR) is used to sense the floor which the elevator is at all times. In a similar case study as this the author provided to further develop the quality in elevator systems and all of these will increase the reliability of elevators. The author also mentioned achieving high speed nine-phase Permanent Magnet Synchronous Motor Control System [5].

Another possibility is making a wireless module to achieve the transmission of user information, PLC control systems are successful for implementation of this kind, the serial communication mode between the PLC and the wireless module was achieved. Single-Chip computers and PLC are usually present in these situations to modify the control system of construction elevators. The control system of the construction elevator was produced using PLC, wireless calling device and wireless host transceiver. With this implementation, the elevator control system can determine the next travel direction based on the call information and the current operation automatically and the most important thing is that it realizes unattended operation [5].

To design this control circuit, it is needed to divide several of the units or thee modules for its particular task and to transform them and combine them with others.

The basis of elevators that use PLC for controlling can be classified into three main groups:

- the first is the floor,

- the PLC controller and

- the elevator.

Using this logic and this design the components can be: PLC controller, DC motor driver, push button, level sensor, display unit and elevator (Figure 4) [6].

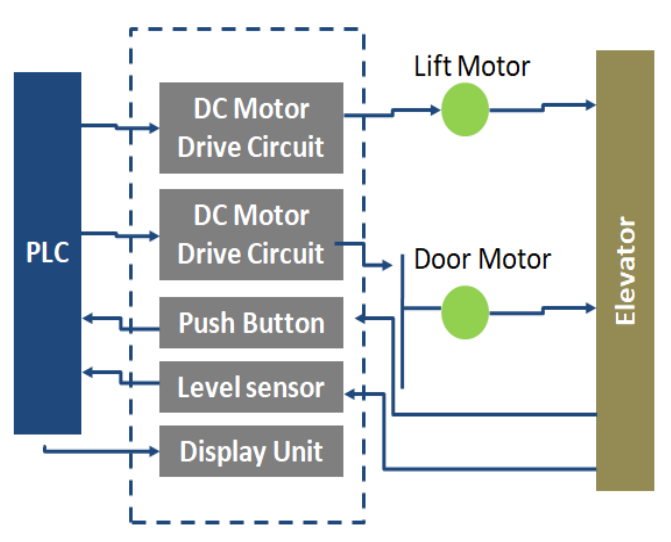

Fig. 4. Block diagram of PLC control system 
Level sensors are present for a reason to know the elevator position at any moment. The push buttons are used to give an input value by the user request. The display unit will, of course, display the number of floors. The main use of the PLC here is to compare the user request and the push button to drive the elevator motor Up or Down. When the user request is greater than the sensor value, the motor will go up and it is less than the sensor value, it will logically go down. When the two values are equal, the motor must stop at every situation [7].

This design can be divided into three units: a sensor unit, processing unit and power unit. Additionally exists devices and components which are used in the design to implement each unit.

The flowchart of an achievable transmitting and receiving message for the elevator control system is shown in the Figiure 5 [8].

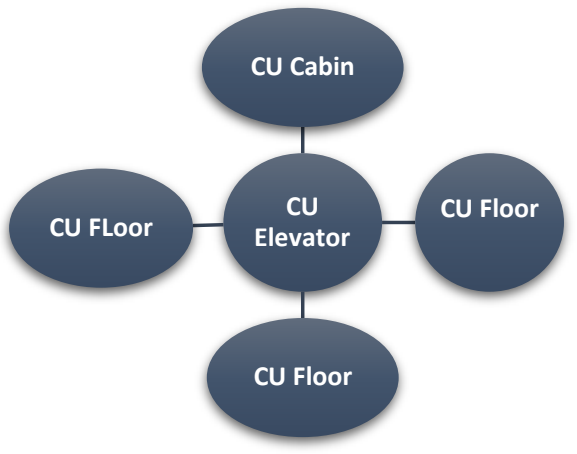

Fig. 5. Block diagram of PLC control system

It consists of a 3 types of CAN messages, green, yellow and red. The red messages have the highest priority while the green messages are the ones with the lowest importance. The protocol is optimized for short messages. The messages that can be exchanged between the CUs of a distributed elevator control system are listed in Table 1.

Table 1

\begin{tabular}{lll}
\multicolumn{3}{c}{ List of messages } \\
\hline \hline Message & Transmitter & Receiver \\
\hline Status of module & CU Floor & CU Elevator \\
Hall call & CU Floor & CU Elevator \\
Status of module & CU Cabin & CU Elevator \\
Cabin in extreme position & CU Cabin & CU Elevator \\
Deceleration / Acceleration & CU Cabin & CU Elevator \\
Cabin on the floor & CU Cabin & CU Elevator \\
Revision instructions & CU Cabin & CU Elevator \\
Floor serviced & CU Cabin & CU Elevator \\
Cabin call & CU Cabin & CU Elevator \\
Call for status & CU Elevator & CU Cabin / Elevator \\
Setting mode & CU Elevator & CU Cabin / Elevator \\
Indicating current cabin position & CU Elevator & CU Cabin / Elevator \\
Indicating cabin direction & CU Elevator & CU Cabin / Elevator \\
Service floor & CU Elevator & CU Cabin / Elevator \\
\hline \hline
\end{tabular}

\section{GREEN ASPECTS}

With the implementation of PLC control tables the idea of smart elevator is born. Changing the 'old-fashioned' devices with modern 'smart' devices is a trend in the last decade [9].

Because the PLC is a computer on its own, more functions can be applied in the conventional elevator so that the elevator can become 'smart'.
A conventional elevator system is operated manually. So, for an elevator to be smart there would be a way for reserving an elevator (example: elevator in a hotel or a headquarters) and will automatically be in the right place at the right time. This could be widely used in buildings under security restrictions as well. A smart elevator system includes:

- an elevator in a building having multiple floors; 
- a controller designed to control the elevator;

- a transportable terminal used by a person to make the reservation to use the elevator;

- a server for connection between the transportable terminal and the control operation;

- transportable terminal detector (near the door) designed in a way when the terminal used to have made the reservation.

In this idea a portable terminal may be a portable smart phone (or even a smart watch) using an app which displays an interface screen for making the reservation. The connection could be realized with Bluetooth or wi-fi [11]. Another aspect which needs to be thoroughly looked at is the energy efficiency. The modern elevator aside from being 'smart' needs to be 'green' as well. The case study follows the trend and gives an objective image of a green elevator which could be controlled by a PLC module. There are a few ways which could improve the current situation of energy consumption. As it was previously stated, a hydraulic elevator spends 30 times more energy than the cable elevator. The cable elevator is using less than the hydraulic but it always uses energy from a power supply.

When an elevator goes down with a heavy load or up with a lightload, the traction machine works as a power generator. This way of generating energy could be used for improving the performances of current elevators and to make them 'eco-friendlier'. On the other hand, a system can be developed which will be a Hybrid Driven Elevator System. Auxiliary hydraulic system is installed to provide energy storage and torque support to a normal cable elevator [12]. With a super-capacitor (SC) bank linked to the DC bus, an extra DC/DC converter is required. The energy conversion chain and the single conversion efficiency of each component are illustrated in Figure 6 . In this configuration is selected a premium efficiency motor. The final total round trip conversion efficiency from the motor to SC and back to the motor is $64.7 \%$. If a battery is used as an alternative of SC, the results could be even better.

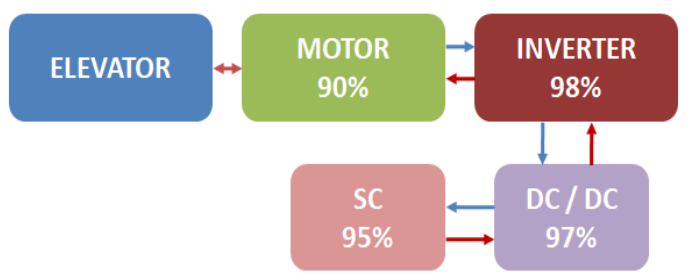

Fig. 6. Energy conversion chain and efficiency of each component
The energy can be accumulated into the accumulator and reused to drive the elevator without going through the electrical system. The conversion efficiency will be a little bit less than $73 \%$.

Analyzing the overall round trip, the conversion efficiency would be slightly higher than that of the SC based approach as in some occasions the energy drawn from the grid is substantial. Nowadays, the problem with pollution has reached its peak due to the development and modernization in our lives. With the development of science and technology, the potential to protect the environment has been grown. First of all to preserve green areas, city environments are increasingly vertical. That's why buildings try to offer greater efficiency than ever before. In urban environments, buildings are the biggest consumers of energy, shown in Figure 7. Statistics by Urban Hub shows that the global energy demand will increase by $20 \%$ to $35 \%$ over the next 15 years with cities accounting for two-thirds of this increase. A lot of innovative technologies and smart devices help to drive down this consumption.

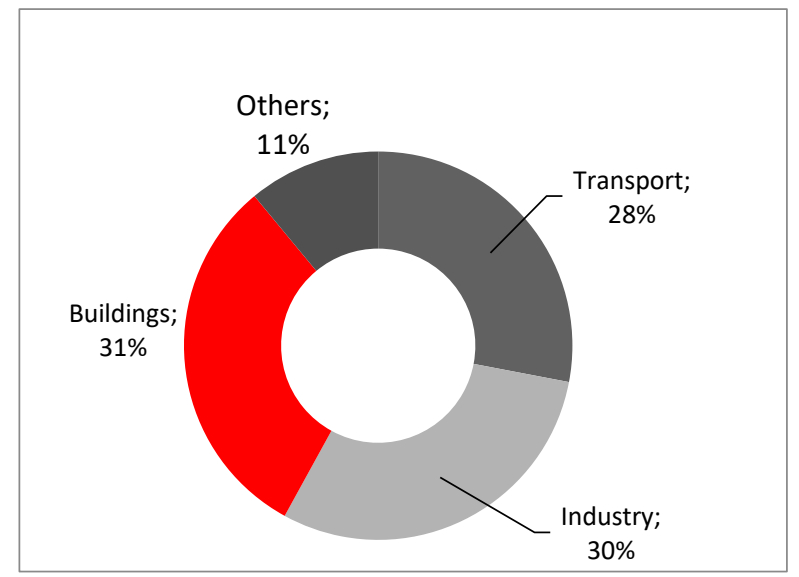

Fig. 7. The largest consumers of global final energy in 2030 (Source: Urban Hub, 2015)

New technologies such as the TWIN elevator - two independently operating cabs in the same shaft - illustrate that can reduce energy consumption by up to $27 \%$ and to reduce electrical power requirements in half while augmenting usable floor space by as much as $30 \%$, as well as, elevators to drive a building's energy self-sufficiency. At the new One World Trade Center in New York City, their elevators' regenerative drives supply enough energy for the building's entire lighting system. Upgrade older elevators can downcrase energy consumption by up to $70 \%$ and increase an elevator's reliability by an additional 25 years [14]. 
According to some research, elevators can be used for energy efficiency in buildings in three aspects. The first, the simplest level of a green elevator is an energy efficiency building. This aspect focuses on the internal factors of the green elevator such as lighting, air changes and mechanical handling equipment, in other words this is clean energy technology. The main goal of clean energy technology is to make the design more able to aid conservation of sunlight and to use night LED lighting. The next stage for creating an ecological environment is to consume renewable and green sources of energy [8].

Every step towards giving rise to green elevators, but the most promising methods of the future green warehouse include energy self-production and sustainable building design [10].

\section{DISCUSTION OF "VALUE" OF GREEN ELEVATORS}

The Schindler solar elevator tries to get closer to realizing an eco-friendly device. The solution lies in usage of as much as possible renewable source of energy - sunlight.

Their solution is a combination of smart power supply - renewable energy from sunlight and a back-up from the grid. This hybrid power manager elevator downcrease energy costs by making ESD is charged with solar energy as much as possible or during the night from the grid when energy costs are low. Not everything is so perfect, of course limits exist. The Schindler 3300 solar elevator can meet the needs of residential and smaller commercial buildings (Figure 8) [15].

This eco-friendly elevator could operate in three modes which are illustrated on the Figure 9 as a single-phase elevator with a power back-up, Figure 10 with a PV-panel installation precisely for the elevator, and on Figure 11 connected to existing PV -panels that could supply the whole building [15].

Furthermore, in addition to the initiative for green elevators, technology that is in development are smart elevators. The solution is to use an electromagnetic levitation technology, the same technology which makes superhigh-speed trains run frictionless along a track by applying magnetic power.

One worldwide famous company is working on a multi-system, rope-free elevator system that applies the same concept, but on a vertical plane. This technology stands for moving multiple cabins vertically and horizontally in a loop.
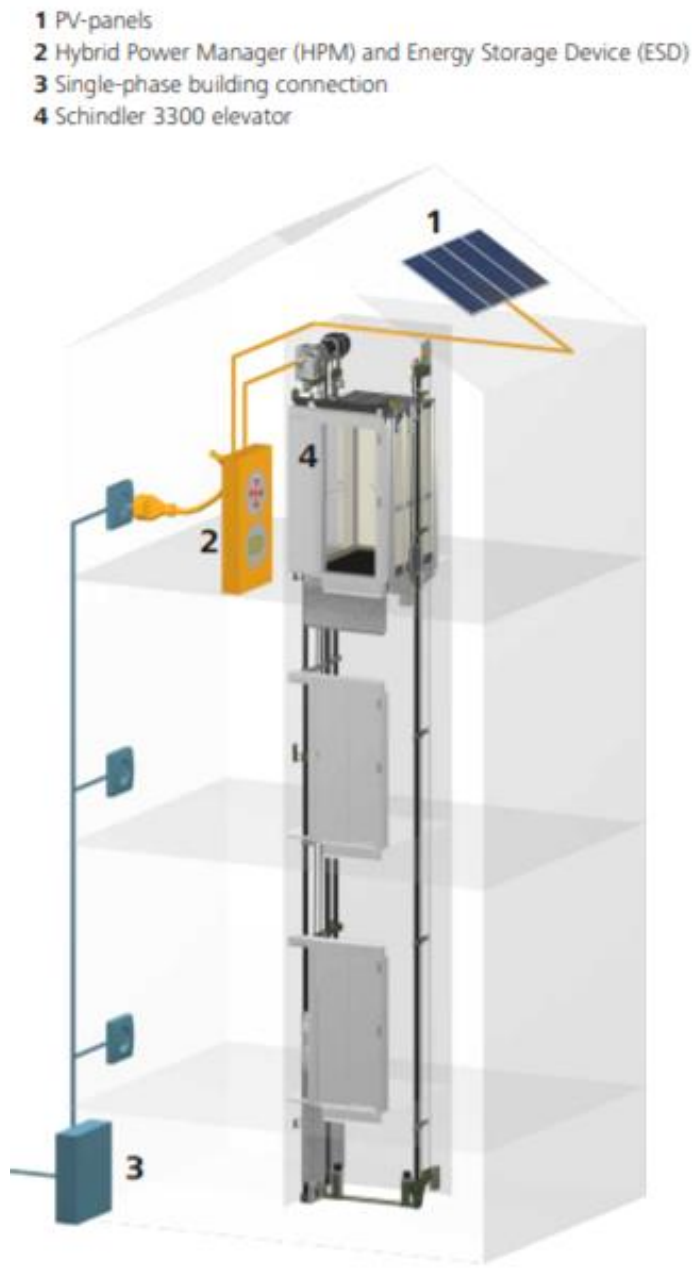

Fig. 8. Instalation of a Schindler 3300 solar elevator [15]

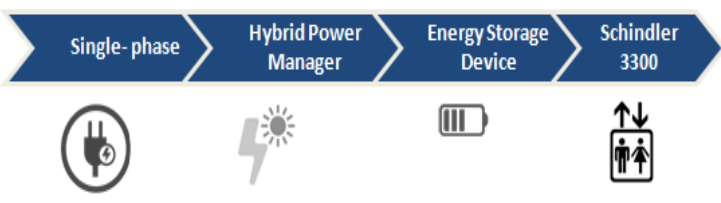

Fig. 9. Plugin mode

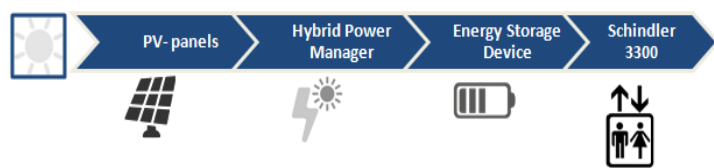

Fig. 10. Solar-dedicated mode

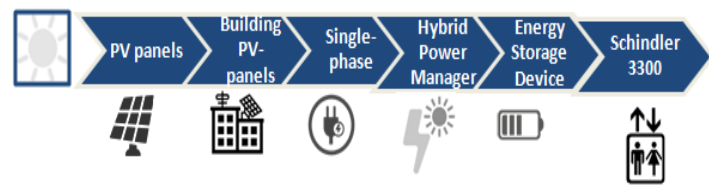

Fig. 11. Solar elevator integrated into PV-panel installation of the building 
Also, the company aims to increase the transport capacity by up to $50 \%$, with a large increase in speed transportation too, whilst offering significant space saving, because the compartments will be much smaller in size. Considering the economics of skyscrapers, this technology can also help. According to the company, the first multi-system elevator will be tested in the upcoming years. [15]

\section{CONCLUSION}

By developing some of the proposed system, the result of the elevator control system can be applied in the real world and especially this can be used in a county like North Macedonia with low development. The data about average daylight / average sunshine in Skopje support this implementation. (Figure 12).
Moreover, with development of a green-smart elevator, the engineering of transport and logistics is going a step closer to a modern world where the industry cares for the ecosystem and the wish of the customer is always the most im-portant thing. Nonetheless, due to the extensive capital investment, for now, it is just an environmentally-friendly method and not a cost-efficient one in a country which is in development. Consequently, choosing an affordable way to renewable energy is a hard task. Solar panels are a very expensive investment and usually require about 15-20 years of payback. Tests need to be carried out to show the effectiveness and flexibility of the proposed methods. This will give an opportunity to grow in engineer-ing fields. For now, the PLC based elevator system is an efficient tool to conserve electricity when the elevator is not in active mode. The overall system ensures high reliability which is one of the most important things.

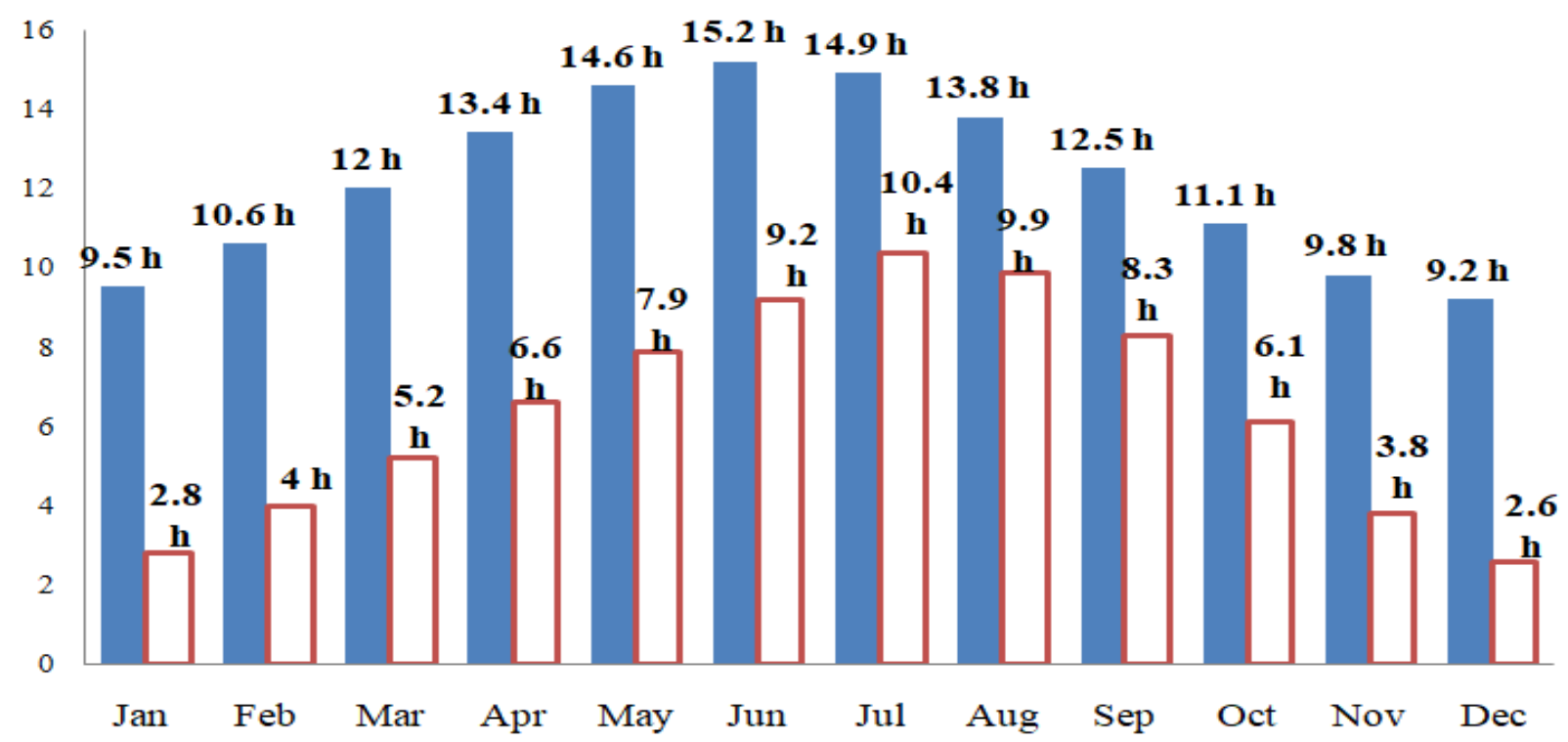

$\square$ Daylight house $\square$ Sunshine hours

Fig. 12. Average daylight / average sunshine in Skopje (Source: Weather Atlas)

\section{REFERENCES}

[1] Gao, Y., Xu, X., Lu, J., Sun, Z., Chen, S., Liu, Z.: Energy consumption braking characteristics analysis for multi-car elevator system, 22nd International Conference on Electrical Machines and Systems, Vol. 19, No. 1, pp. 1-13 (2019).

[2] Covington, M. A.: Logical control of an elevator with defensible logic, IEEE Transactions on Automatic Control, vol. 45, No. 7, pp. 1347-1349 (2000).

[3] Yang, X., Zhu, Q., Xu, H.: Design and practice of an elevator control system based on PLC, 2008 Workshop on
Power Electronics and Intelligent Transportation System, IEE Computer Society, Vol. 1, pp. 94-99 (2008).

[4] RonCarter, S. B.: Design and implementation of PLC based elevator, International Journal of Computer Applications, Vol. 68, No. 7, pp. 4-10 (2013).

[5] Caiqiao Wei: Design of control system of construction elevator based on PLC, 4th Electronic System Integration Technology Conference, 2012, pp. 108-111.

[6] Sandar, Htay. Su Su Yi, Mon: Implementation of PLC based elevator control system, International Journal of Electronics and Computer Science Engineering, IJECSE, Vol. 3, No. 2, pp. 91-100 (2014). 
[7] Pillay, P., Krishnan, R.: Modeling of DC motor drives, IEEE Trans. Industry Applications, Vol. 35, No. 4, pp. 537-541 (1988).

[8] Lee, K. C., Lee, H.-H.: Network-based fire-detection system via CAN for smart home automation, IEEE Transactions on Consumer Electronics, Vol. 50, No. 4, pp. 1093-1100 (2004).

[9] Huseinbegović, S., Kreso, S., Tanović, O.: Design and implementation of the CAN based elevator control system, 2009 XXII International Symposium on Information, Communication and Automation Technologies. 29-31 Oct. 2009.

[11] Hanif, M., Mohammad, N., Harun, B.: An effective combination of microcontroller and PLC for home automation system, 1st International Conference on Advances in Sci- ence, Engineering and Robotics Technology (ICASERT), No. CFP19S84-POD. 2019, pp. 1456-1462.

[12] Zhao, B., Quan, Z., Li, Y. W., Quan, L., Hao, Y., Ding, L.: A hybrid driven elevator system with energy regeneration and safety enhancement, IEEE Transactions on Industrial Electronics, 0278-0046 (c) (2019).

[13] Brandon Gaille: https://brandongaille.com/22-elevatorindustry-statistics-trends-analysis/, www. brandongaille.com (2018).

[14] https://www.urban-hub.com/sustainability/raising-thegreen-in-urban-buildings-with-modern-elevatortechnologies/, www.urbanhub.com, 2015.

[15] Schindler 33 Solar (Brochure), NIB-SM. Schindler 3300 Solar.GB EN.03, www.schindler.com, 2015. 